The Wilderness Itineraries 


\section{Edited by}

Jeffrey A. Blakely University of Wisconsin, Madison

K. Lawson Younger Trinity Evangelical Divinity School

1. The Horsemen of Israel: Horses and Chariotry in Monarchic Israel (NinthEighth Centuries B.C.E.), by Deborah O'Daniel Cantrell

2. Donkeys in the Biblical World: Ceremony and Symbol, by Kenneth C. Way

3. The Wilderness Itineraries: Genre, Geography, and the Growth of Torah, by Angela R. Roskop 


\title{
The Wilderness Itineraries
}

\author{
Genre, Geography, and \\ the Growth of Torah
}

Angela R. Roskop

Winona Lake, Indiana

EISENBRAUNS

2011 


\author{
(C) 2011 by Eisenbrauns Inc. \\ All rights reserved \\ Printed in the United States of America \\ www.eisenbrauns.com
}

\title{
Library of Congress Cataloging-in-Publication Data
}

Roskop, Angela R.

The wilderness itineraries : genre, geography, and the growth of Torah / Angela R. Roskop.

p. $\quad$ cm. - (History, archaeology, and culture of the Levant ; vol. 3) Includes bibliographical references and indexes.

ISBN 978-1-57506-212-9

1. Bible. O.T. Pentateuch-Criticism, Narrative. 2. Bible. O.T. Numbers XXXIII-Criticism, interpretation, etc. 3. Bible. O.T. Pentateuch-

Geography. 4. Travel in the Bible. 5. Bible. O.T. Pentateuch-Chronology.

6. Chronology, Historical. I. Title.

BS1225.52.R67 2011

$222^{\prime} .1066-\mathrm{dc} 22$

2011010052

The paper used in this publication meets the minimum requirements of the American National Standard for Information Sciences - Permanence of Paper for Printed Library Materials, ANSI Z39.48-1984.@ $\otimes^{\mathrm{TM}}$ 


\section{In Memoriam \\ Milo Francis Hagan \\ 1922-1991}

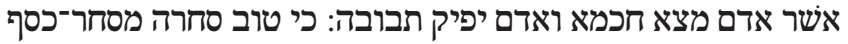

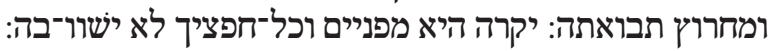

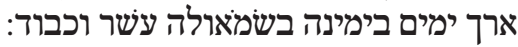
דרכיה דרכי־נעם וכל־נתיביבותיה שיח שלום וכבוד:
עץ־חיים היא למחזיקים בה ותמכליכתיה מאיה שלום:
משלי ג:יג-יח

We have to learn to think differently-in order, at last, perhaps very late on, to attain even more: to feel differently.

Friedrich Nietzsche 
